\title{
Purification and Characterization of a Bacteriocin, BacBS2, Produced by Bacillus velezensis BS2 Isolated from Meongge Jeotgal
}

\author{
Venkatesh Perumal ${ }^{1}$, Zhuang Yao ${ }^{2}$, Jeong A Kim ${ }^{2}$, Hyun-Jin Kim ${ }^{1,2}$, and Jeong Hwan Kim ${ }^{1,2 *}$ \\ ${ }^{1}$ Institute of Agriculture and Life Science, Gyeongsang National University, Jinju 52828, Republic of Korea \\ ${ }^{2}$ Division of Applied Life Science (BK21 Plus), Graduate School, Gyeongsang National University, Jinju 52828, Republic of Korea
}

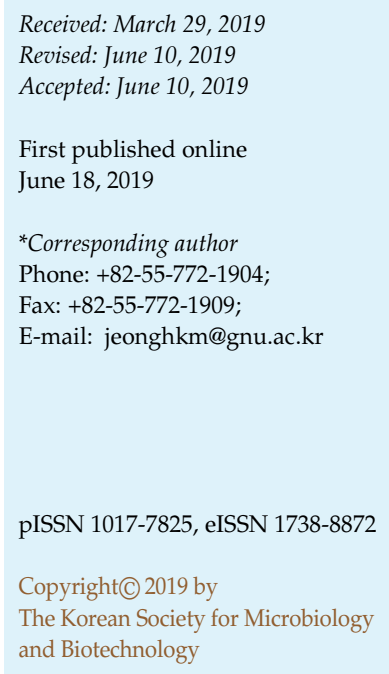

Bacillus velezensis BS2 was isolated from meongge (common sea squirt) jeotgal, a Korean fermented seafood, and produces a bacteriocin, BacBS2, which strongly inhibits Listeria monocytogenes and Bacillus cereus. BacBS2 was partially purified by Q-Sepharose column chromatography after ammonium sulfate precipitation of the culture supernatant, then further purified by Sephadex G-50 column chromatography. Partially purified BacBS2 was estimated to be $6.5 \mathrm{kDa}$ in size by Tricine-SDS PAGE and activity detection by gel-overlay. Enzyme treatment and FT-IR spectrum of partially purified BacBS2 confirmed its proteinaceous nature. BacBS2 was fully stable at $\mathrm{pH} 4-9$, and half of activity was retained at $\mathrm{pH} 1-3$. Full activity was retained after exposure to $80^{\circ} \mathrm{C}$ for $15 \mathrm{~min}$, but half of the activity was retained upon exposure to $90^{\circ} \mathrm{C}$ for $15 \mathrm{~min}$ or $100^{\circ} \mathrm{C}$ for $10 \mathrm{~min}$. BacBS2 inhibited L. monocytogenes by bactericidal mode of action. B. velezensis BS2 and its BacBS2 seem useful as biopreservatives for fermented foods such as jeotgal.

Keywords: Bacteriocin, Bacillus velezensis, antibacterial activity, jeotgal

\section{Introduction}

Genus Bacillus are Gram-positive, aerobic, rod-shaped bacteria including more than 300 species, with many being industrially important [1]. Many Bacillus species are wellknown producers for diverse antimicrobial compounds such as bacteriocins and lipopeptides [2]. Well known antimicrobial compounds synthesized by Bacillus spp. are bacteriocins or bacteriocin-like substances (BLIS) [3]. Bacteriocins are peptides or proteins with antimicrobial activity against closely related species of the producer. But bacteriocins differ in properties such as molecular weight, modification after production, biochemical properties, antimicrobial spectrum, and mode of action.

Bacteriocins produced by lactic acid bacteria (LAB) and Bacillus sp. are potential bio-preservatives as alternatives to chemical preservatives because of their GRAS (generally recognized as safe) status [4]. However, to date, only a few bacteriocins are commercially available such as Nisin and Pediocin PA-1, which are produced by Lactococcus lactis and Pediococcus acidilactici, respectively. But Nisin and Pediocin PA-1 alone do not fulfill all the desired requirements (broad antimicrobial spectrum and active at extreme $\mathrm{pHs}$ ) to be used as food preservatives. Hence, worldwide research is ongoing to find novel bacteriocinproducing microorganisms from various sources. Bacteriocins produced by Bacillus sp. are reported to have a wide antimicrobial spectrum and be active at extreme $\mathrm{pH}$ and temperature $[5,6]$.

In recent years, non-dairy fermented foods have become popular as sources to isolate potential probiotic LAB and Bacillus sp. In this study, a bacteriocin produced by Bacillus velezensis BS2 was characterized and partially purified. B. velezensis BS2 was isolated from meongge (common sea squirt, Halocynthia roretzi) jeotgal, a Korean salted and fermented seafood [7]. B. velezensis is a novel species that was recently taxonomically classified to differentiate it from a closely related species, B. amyloliquefaciens [8]. B. velezensis strains are broadly distributed in different environmental niches including fermented foods, soil, and 
water $[8,9]$. B. velezensis can be used as a starter culture for fermented foods, and also as a probiotic for animal feed as an alternative to antibiotics $[8,10]$. Some soil isolates have very good potential as plant growth promoters as well as biocontrol agents against fungal infection in plants [11]. A Brazillian Amazon basin isolate, B. velezensis P11, showed strong keratinolytic, proteolytic, and dehairing activities, which could be used for some industrial applications [12]. Apart from the production of various antimicrobial substances such as lipopeptides and bacteriocins, $B$. velezensis strains have been known to be harmless to hosts and environments with strong stress tolerance, making this species able to grow at different ranges of temperature $\left(15^{\circ} \mathrm{C}\right.$ to $45^{\circ} \mathrm{C}$ ) and $\mathrm{pH}$ (5 to 10) [13]. B. velezensis strains with antimicrobial activities have been reported, and the genes responsible for antimicrobial activities were identified on the chromosome by genome sequencing [14-16]. But few studies on bacteriocins have been conducted. As far as we know, this is the first report on the purification of a bacteriocin from $B$. velezensis strain originated from marine environments. A B. velezensis strain producing bacteriocin could be useful as a food preservative or biocontrol agent.

\section{Materials and Methods}

\section{Bacterial Cultures and Media}

B. velezensis BS2 was isolated from sea squirt jeotgal, a Korean fermented seafood, and identified by $16 \mathrm{~S}$ rRNA and recA gene sequencing [7]. Indicator strains (Table 1) were either obtained from culture collection centers or our lab culture stocks. All Bacillus strains used in this study were grown at $37^{\circ} \mathrm{C}$ in one of the following media: Luria Bertani (LB, MB cell, Korea); brain heart infusion (BHI, MB cell); nutrient broth (NB, Acumedia, USA); tryptic soy broth (TSB, Becton, Dickinson and Company, Sparks, USA); and Mueller Hinton agar (MH, MB cell). Lactic acid bacteria (LAB) were grown at $37^{\circ} \mathrm{C}$ in de Man, Rogosa, and Sharpe medium (lactobacilli MRS, Becton, Dickinson and Company).

\section{Antibacterial Spectrum of B. velezensis BS2}

Antibacterial spectrum of B. velezensis BS2 was examined using agar well diffusion assay [16]. In brief, $\mathrm{MH}$ agar plates were overlaid with $9 \mathrm{ml}$ of $\mathrm{MH}, \mathrm{LB}, \mathrm{MRS}$ or BHI soft agar inoculated with $50 \mu \mathrm{l}$ of each indicator strain, which was previously grown until the $\mathrm{OD}_{600}$ value reached 0.4-0.8. Wells were made on the seeded plates using a sterile Pasteur pipette and culture supernatant $(50 \mu \mathrm{l}, \mathrm{pH} 7.0)$ from B. velezensis BS2 was added into each well. The plates were incubated overnight at $37^{\circ} \mathrm{C}$ or $30^{\circ} \mathrm{C}$ and then inhibition zones were examined. The activity of bacteriocin was determined by the two-fold serial dilution method. For this, cell-free supernatant (CFS) was 2-fold serially diluted, and each dilution was examined. Bacteriocin activity was
Table 1. Inhibition spectrum of BacBS2 against different bacterial indicator strains.

\begin{tabular}{lcc}
\hline \multicolumn{1}{c}{ Indicator strains } & BS2 & EMD4 \\
\hline Bacillus cereus ATCC14579 & +++ & +++ \\
Bacillus licheniformis ATCC21415 & - & - \\
Bacillus subtilis & - & - \\
Bacillus thuringiensis ATCC33679 & +++ & +++ \\
Escherichia coli O157: H7 & - & - \\
Escherichia coli v517 & - & - \\
Enterococcus faecalis ATCC29212 & +++ & + \\
Enterococcus faecium ATCC19953 & +++ & + \\
Lactobacillus caesei spp. casei ATCC4646 & - & - \\
Lactobacillus delbrueckii spp. lactis ATCC4797 & +++ & - \\
Lactobacillus pentosus ATCC8041 & - & - \\
Leuconostoc mesenteroides ATCC9135 & +++ & - \\
Listeria monocytogenes ATCC19111 & +++ & ++ \\
Pediococcus pentosaceus NRRL B-14009 & - & + \\
Salmonella Typhimurium TA98 & - & - \\
Salmonella Typhimurium TA100 & - & - \\
Streptococcus thermophilus & + & + \\
Staphylococcus aureus & - & -
\end{tabular}

,+ 0.5 to $2 \mathrm{~mm}$ (moderate inhibitory activity); ++, 2 to $4 \mathrm{~mm}$ (strong inhibitory activity); +++ , more than $4 \mathrm{~mm}$ (very strong inhibitory activity). All the strains were revived two times from glycerol stock before being used as indicators.

defined as the reciprocal of the highest dilution that still gave a definite zone of inhibition and expressed as activity units (AU) per $\mathrm{ml}$ after being multiplied by a conversion factor.

Effect of Culture Medium on the Growth and Bacteriocin Activity of B. velezensis BS2

For this, overnightly grown $B$. velezensis BS2 was $1 \%(\mathrm{v} / \mathrm{v})$ inoculated into five different media ( $\mathrm{LB}, \mathrm{NB}, \mathrm{TSB}, \mathrm{BHI}$, and $\mathrm{MH})$, and then cultivated for $96 \mathrm{~h}$ at $37^{\circ} \mathrm{C}$ with aeration. The $\mathrm{OD}_{600}$ values and bacteriocin activity of each culture were measured at $6 \mathrm{~h}$ intervals during the first $24 \mathrm{~h}$ and then $12 \mathrm{~h}$ intervals after $24 \mathrm{~h}$. Agar well diffusion method was used for the antimicrobial activity measurements and Listeria monocytogenes ATCC19111 was used as an indicator.

\section{Stability of Bacteriocin Activity against pH, Heat, and Enzyme Treatments}

Activity of BacBS2 (bacteriocin produced by B. velezensis BS2) was measured at different $\mathrm{pH}$, temperature, and enzyme treatments (Table 2). CFS of B. velezensis BS2 was used as the crude bacteriocin sample for the experiments. For testing $\mathrm{pH}$ stability, crude BacBS2 sample was adjusted to $\mathrm{pH}$ 1-12 using $1 \mathrm{~N}$ $\mathrm{HCl}$ or $1 \mathrm{~N} \mathrm{NaOH}$. The $\mathrm{pH}$-adjusted CFSs were incubated for $3 \mathrm{~h}$ at $37^{\circ} \mathrm{C}$ and then the $\mathrm{pH}$ again adjusted to 7 , and the bacteriocin 
Table 2. Stability of BacBS2 upon treatment of different $\mathrm{pH}$, heat and enzymes.

\begin{tabular}{|c|c|c|c|c|c|}
\hline $\mathrm{pH}$ & $\begin{array}{l}\text { Remaining activity } \\
(\mathrm{AU} / \mathrm{ml})\end{array}$ & $\begin{array}{l}\text { Heat treatment } \\
\qquad(15 \mathrm{~min})\end{array}$ & $\begin{array}{l}\text { Remaining activity } \\
(\mathrm{AU} / \mathrm{ml})\end{array}$ & Enzyme treatment & $\begin{array}{c}\text { Remaining activity } \\
(\mathrm{AU} / \mathrm{ml})\end{array}$ \\
\hline Control $^{1}$ & 320 & Control & 320 & Control & 320 \\
\hline 1 & 160 & $50^{\circ} \mathrm{C}$ & 320 & Protease & 160 \\
\hline 2 & 160 & $60^{\circ} \mathrm{C}$ & 320 & Pepsin & 320 \\
\hline 3 & 160 & $70^{\circ} \mathrm{C}$ & 320 & Trypsin & 320 \\
\hline 4 & 320 & $80^{\circ} \mathrm{C}$ & 320 & Proteinase-K & 0 \\
\hline 5 & 320 & $90^{\circ} \mathrm{C}$ & 160 & & \\
\hline 6 & 320 & $100^{\circ} \mathrm{C}^{2}$ & 160 & & \\
\hline 7 & 320 & & & & \\
\hline 8 & 320 & & & & \\
\hline 9 & 320 & & & & \\
\hline 10 & 160 & & & & \\
\hline 11 & 0 & & & & \\
\hline 12 & 0 & & & & \\
\hline
\end{tabular}

${ }^{1}$ Control was a bacteriocin sample (CFS) that was not $\mathrm{pH}$ adjusted, heat-treated, or enzyme treated.

${ }^{2} 10$ min exposure.

activities were checked. CFS without $\mathrm{pH}$ adjustment was used as a control.

For testing heat stability, crude BacBS2 samples were heated for $15 \mathrm{~min}$ at $50^{\circ} \mathrm{C}, 60^{\circ} \mathrm{C}, 70^{\circ} \mathrm{C}, 80^{\circ} \mathrm{C}$, and $90^{\circ} \mathrm{C}$, and for $10 \mathrm{~min}$ at $100^{\circ} \mathrm{C}$. After incubation, samples were allowed to cool at room temperature before checking the residual activities. A sample without heat treatment was used as a control. For proteolytic enzyme treatments, a $1 \mathrm{mg} / \mathrm{ml}$ concentration of pepsin, trypsin, protease, and proteinase-K (Sigma-Aldrich, USA) was added to a crude BacBS2 sample and then incubated at $37^{\circ} \mathrm{C}$ for $2 \mathrm{~h}$ before checking the residual activities. A bacteriocin sample without any enzyme treatment was used as a control. The residual activities of all the samples along with control were measured by agar well diffusion assay using L. monocytogenes ATCC19111 as an indicator. After overnight incubation, the activity units were calculated.

\section{Purification of BacBS2}

CFS was obtained from B. velezensis BS2 culture grown for $48 \mathrm{~h}$ in LB by centrifuging at $6,000 \times g$ for $1 \mathrm{~h}$ at $4^{\circ} \mathrm{C}$. Ammonium sulfate precipitation $(80 \%$ saturation) was performed with the obtained CFS for overnight at $4^{\circ} \mathrm{C}$. Then bacteriocin pellet was collected by centrifuging at 6,000 $\times g$ for $1 \mathrm{~h}$ at $4^{\circ} \mathrm{C}$, and dissolved in minimum volume of buffer A ( $20 \mathrm{mM}$ Tris- $\mathrm{HCl}, \mathrm{pH} 7.0)$, and dialyzed against the same buffer using a $1 \mathrm{kDa}$ cut-off dialysis bag (Sigma-Aldrich) for $24 \mathrm{~h}$ with 4 buffer changes.

Dialyzed bacteriocin was lyophilized and dissolved in $1 \mathrm{ml}$ of buffer A. Ion-exchange chromatography was done using a QSepharose fast flow column (Amersham Pharmacia Biotech., Sweden) $(2.5 \times 11 \mathrm{~cm})$. Buffer A was the eluent with $0.2 \mathrm{M} \mathrm{NaCl}$ gradient from 0-1 M. A total of 120 fractions were collected with $10 \mathrm{ml}$ each and the absorbance of each fraction was measured at
$280 \mathrm{~nm}$. Antimicrobial activity of each fraction was checked by agar well diffusion method against L. monocytogenes ATCC19111. Fractions showing antimicrobial activity were pooled, dialyzed, and concentrated by lyophilization. The lyophilized sample was dissolved into $1 \mathrm{ml}$ of buffer $\mathrm{A}$ and further purified by size exclusion column chromatography using a Sephadex G-50 (Amersham Pharmacia Biotech.) $(1.5 \times 90 \mathrm{~cm})$. The eluent was collected into 60 fractions containing $5 \mathrm{ml}$ each. Fractions showing antimicrobial activity were pooled, dialyzed and lyophilized. The active fractions were checked by SDS-PAGE and the protein concentration was analyzed by the Bradford method using a kit (BioRad, USA) and BSA (bovine serum albumin) as a standard [17].

\section{Size of BacBS2 and FT-IR Analysis}

The size of the partially purified BacBS2 was determined by Tricine SDS-PAGE [18]. Fifty $\mu \mathrm{g}$ of BacBS2 sample in $1 \times$ SDSPAGE loading buffer was loaded into $16 \%$ polyacrylamide gel, and the electrophoresis was done at $110 \mathrm{~V}$ constantly. After the run, the gel was cut into two halves, each containing the sample. One half was washed with buffer A for at least $4 \mathrm{~h}$ with buffer changes at every $30 \mathrm{~min}$. Then the gel was overlaid with soft agar containing the indicator strain, L. monocytogenes ATCC19111 $\left(\mathrm{OD}_{600} 0.4-0.8\right)$. After overnight incubation at $37^{\circ} \mathrm{C}$, the zone of inhibition was observed. The other half of the gel was stained with Coomassie brilliant blue R-250 as previously described [19].

Functional groups in partially purified BacBS2 were analyzed by FTIR spectrometry (Vertex $80 \mathrm{v}$, Bruker, USA) in transmission mode for the range between $4,000-400 \mathrm{~cm}^{-1}$ with a resolution of $4 \mathrm{~cm}^{-1}$. 
Table 3. Primers used for the amplification of selected antimicrobial genes from B. velezensis BS2.

\begin{tabular}{|c|c|c|c|c|c|c|}
\hline Lipopeptides & Gene & Primers & Sequence $\left(5^{\prime}\right.$ to $\left.3^{\prime}\right)$ & Product size (bp) & $+/-$ & Reference \\
\hline \multirow[t]{6}{*}{ Surfactin } & $\operatorname{srfA}$ & SRFA-F & TCGGGACAGAAGACATCAT & 201 & ++ & [21] \\
\hline & & SRFA-R & CCACTCAAACGGATAATCCTGA & & & \\
\hline & Srf/lch & As1-F & CGCGGMTACCGVATYGAGC & 424 & ++ & [22] \\
\hline & & Ts2-R & ATVCCTTTBTWDGAATGTCCGCC & & & \\
\hline & $s f P$ & SFP-F1 & ATGAAGATTTACGGAATTTA & 675 & -- & [21] \\
\hline & & SFP-R1 & TTATAAAAGCTCTTCGTACG & & & \\
\hline \multirow[t]{2}{*}{ Fengycin } & fen & Af2-F & GAATAYMTCGGMCGTMTKGA & 443,452 & -- & [22] \\
\hline & & Tf1-R & GCTTTWADKGAATSBCCGCC & & & \\
\hline \multirow[t]{2}{*}{ Iturin } & $i t u D$ & ITUD-F1 & TTGAAYGTCAGYGCSCCTTT & 482 & ++ & [21] \\
\hline & & ITUD-R1 & TGCGMAAATAATGGSGTCGT. & & & \\
\hline \multirow[t]{2}{*}{ Iturin A } & $i t u A$ & ITUD1F & GATGCGATCTCCTTGGATGT & 647 & ++ & [23] \\
\hline & & ITUD1R & ATCGTCATGTGCTGCTTGAG & & & \\
\hline \multicolumn{7}{|l|}{ Bacteriocins } \\
\hline \multirow[t]{2}{*}{ Subtilin } & spas & SpaS-Fwd & CAAAGTTCGATCATTTCGATTTGGATGT & 152 & -- & [24] \\
\hline & & SpaS-Rev & GCAGTTACAAGTTAGTGTTTGAAGGAA & & & \\
\hline \multirow[t]{2}{*}{ Subtilosin A } & $s b o A$ & sboA-F & GTACAACATAGATCTGCTAG & 400 & -- & [20] \\
\hline & & sboA-R & GCTGGTGAACTCTTACAC & & & \\
\hline \multirow[t]{2}{*}{ Amylocyclicin } & $\operatorname{acn} A$ & amycy-F & CTGTTGAGTTGAGGAATGCCC & 702 & ++ & This study \\
\hline & & amycy-R & TATGCTGCCGCAGGAAAACT & & & \\
\hline
\end{tabular}

,++ amplified and the product showed the expected size; --, not amplified; +-, amplified but the product showed different size.

\section{PCR Detection of Antimicrobial Genes}

PCR was carried out to detect genes responsible for the synthesis of antimicrobial substances such as surfactin, fengycin, iturin, iturin A, subtilin, subtilosin A, and amylocylicin. For this, total genomic DNA was extracted from overnightly grown B. velezensis BS2 culture using a G-spin Genomic DNA Extraction Kit (iNtRON, Korea). Primers used are shown in Table 3 and an MJ Mini PCR machine (BioRad, USA) was used. The reaction mixture $(50 \mu \mathrm{l})$ contained $2 \mu \mathrm{l}$ of template DNA, $2 \mu \mathrm{l}$ of each primer $(10 \mu \mathrm{M}), 5 \mu \mathrm{l}$ of dNTPs $(0.25 \mathrm{mM})$, and $1 \mu \mathrm{l}$ of ExTaq DNA polymerase (Takara, Japan). The cycling conditions were as follows: $95^{\circ} \mathrm{C}$ for $4 \mathrm{~min}, 40$ cycles of $94^{\circ} \mathrm{C}$ for $30 \mathrm{sec}, 43-59^{\circ} \mathrm{C}$ for $30 \mathrm{sec}, 72^{\circ} \mathrm{C}$ for $30 \mathrm{sec}$, and a final extension at $72^{\circ} \mathrm{C}$ for $2 \min$ [20]. After amplification, $\mathrm{PCR}$ products were run and visualized on an agarose gel.

\section{Mode of Action of BacBS2}

Partially purified BacBS2 was used in this assay. LB broth $(20 \mathrm{ml})$ was $1 \%$ inoculated with overnight culture of $L$. monocytogenes ATCC19111. Inoculated broth was grown until it reached the exponential phase of growth $(\mathrm{OD} 600=0.68)$. Then $2 \mathrm{ml}(50 \mu \mathrm{g} / \mathrm{ml})$ of BacBS2 sample was added. Two $\mathrm{ml}$ of LB broth was added to another tube as a negative control. Culture tubes were shaken at $37^{\circ} \mathrm{C}$ and the viable cells were counted at every $3 \mathrm{~h}$ for the next $12 \mathrm{~h}$ period.

\section{Results and Discussion}

\section{Antibacterial Spectrum of B. velezensis BS2}

The antibacterial spectrum of $B$. velezensis BS2 was studied against various Gram-positive and negative bacterial species (Table 1). Bacteriocin-producing B. subtilis EMD4 was used as a positive control along with B. velezensis BS2 [19]. Based on the diameter of the inhibition zone observed from the agar plates, the antibacterial activities were described as moderate (less than $2 \mathrm{~mm}$ ), strong (2 to $4 \mathrm{~mm}$ ) and very strong (more than $4 \mathrm{~mm}$ ). At $\mathrm{pH} \mathrm{7,} \mathrm{BacBS2}$ showed similar inhibition spectrum of BacEMD4 against the used indicator strains. BacBS2 showed very strong inhibition against L. monocytogenes ATCC19111 and B. cereus ATCC14579. BacEMD4 also inhibited B. cereus ATCC14579 very strongly but inhibited L. monocytogenes ATCC19111 at a reduced degree.

BacBS2 showed very strong activity against LAB strains, Enterococcus faecalis ATCC29212, Enterococcus faecium ATCC19953, Lactobacillus delbrueckii spp. lactis ATCC4797, and Leuconostoc mesenteroides ATCC9135. On the contrary, BacEMD4 did not show any strong activity against the aforementioned LAB indicator strains. Commercially 

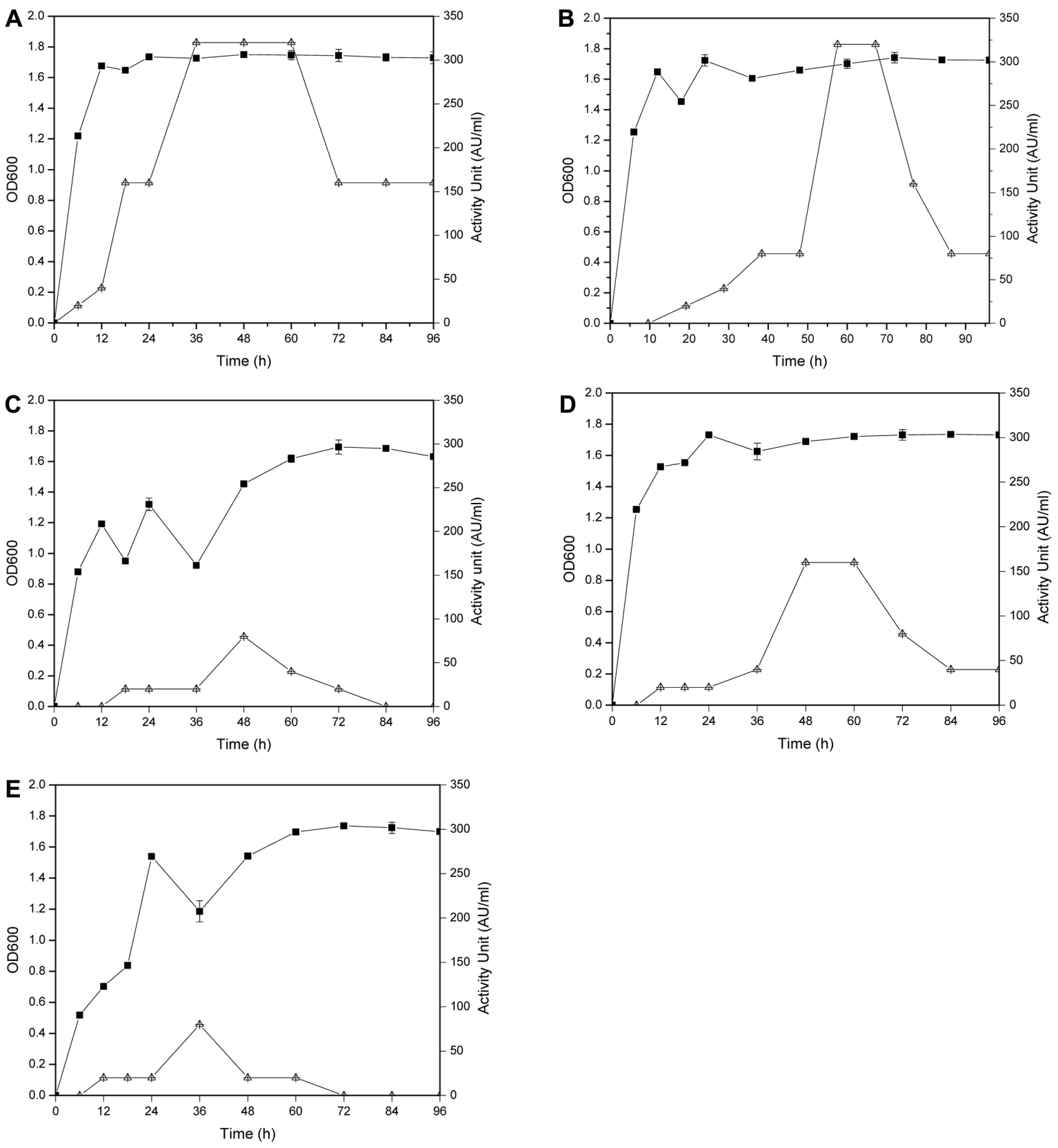

Fig. 1. Growth and antimicrobial activity of B. velezensis BS2 on different growth media.

Luria Bertani broth (A); tryptic soy broth (B); nutrient broth (C); brain heart infusion broth (D); and Mueller Hinton broth (E).

$\longrightarrow$, growth $\left(\mathrm{OD}_{600}\right) ;$, bacteriocin activity $(\mathrm{AU} / \mathrm{ml})$.

available bacteriocins Nisin and Pediocin PA-1 are either weak or not active against L. monocytogenes and B. cereus [25]. Hence, the strong inhibition activity of BacBS2 against L. monocytogenes ATCC19111 and B. cereus ATCC 14579 can be considered as a big advantage of BacBS2 to be used as a natural bio-preservative in foods.

\section{Effect of Culture Medium on the Growth and Bacteriocin} Activity of B. velezensis BS2

The best growth medium and optimum culture conditions will be different for each strain and should be decided individually [19]. B. velezensis BS2 was grown in different media to find out the optimum medium for its 
bacteriocin activity and growth (Fig. 1). In LB broth, B. velezensis BS2 showed higher activity $(320 \mathrm{AU} / \mathrm{ml})$ at $36 \mathrm{~h}$ and retained this activity until $60 \mathrm{~h}$, then the activity was decreased to $160 \mathrm{AU} / \mathrm{ml}$ and retained until $96 \mathrm{~h}$. In TSB, B. velezensis BS2 attained $320 \mathrm{AU} / \mathrm{ml}$ at $48 \mathrm{~h}$ and retained the same activity until $60 \mathrm{~h}$ and then gradually decreased. In BHI broth, B. velezensis BS2 showed bacteriocin activity from $12 \mathrm{~h}$ to all the tested time intervals with a maximum of $160 \mathrm{AU} / \mathrm{mL}$ from 48 to $60 \mathrm{~h}$. In NB and $\mathrm{MH}$ broth, $B$. velezensis BS2 showed lower activity (maximum, $80 \mathrm{AU} / \mathrm{ml}$ ) and the activity was not prolonged in all the tested time intervals. Unlike bacteriocin activity, all media successfully supported the growth of B. velezensis BS2, reaching maximum growth from 1.69 to 1.75 at $\mathrm{OD}_{600}$ in different time intervals. LB broth was the best because B. velezensis BS2 showed the maximum activity $(320 \mathrm{AU} / \mathrm{ml})$ at $36 \mathrm{~h}$ and maintained this activity until $60 \mathrm{~h}$. TSB is the next best medium.

\section{Stability of Bacteriocin Activity against $\mathrm{pH}$, Heat, and Enzyme Treatments}

BacBS2 remained fully active after being treated with proteolytic enzymes, pepsin and trypsin but retained half of the activity after treatment with protease, and lost all activity upon the treatment of proteinase-K (Table 2). These observations confirmed the proteinaceous nature of BacBS2. BacBS2 maintained complete activity after exposure to $50^{\circ} \mathrm{C}$ to $80^{\circ} \mathrm{C}$ for $15 \mathrm{~min}$, and lost half of the activity upon exposure to $90^{\circ} \mathrm{C}$ for $15 \mathrm{~min}$, and $100^{\circ} \mathrm{C}$ for $10 \mathrm{~min}$. These results proved the significant thermal stability of BacBS2. Further, BacBS2 was fully active at $\mathrm{pH} 4$ to $\mathrm{pH}$ 9. BacBS2 showed half activity at $\mathrm{pH} 1-3$ and $\mathrm{pH} 10$, and no activity was observed at $\mathrm{pH} 11$ and 12.

\section{Purification of BacBS2}

A 1,900-ml CFS from B. velezensis BS2 culture (a specific activity $803 \mathrm{AU} / \mathrm{mg}$ protein) was the starting material for BacBS2 purification. After ammonium sulphate precipitation, the specific activity of BacBS2 was calculated to be $1,003.9 \mathrm{AU} / \mathrm{mg}$ protein with $53.9 \%$ yield. Then it was further purified by ion exchange chromatography using QSepharose fast flow resin. Fractions 45 to $54(98 \mathrm{ml})$, which were eluted with buffer A containing $0.4 \mathrm{M} \mathrm{NaCl}$ (Fig. 2A), showed antibacterial activity against L. monocytogenes ATCC19111 by agar well diffusion assay. The collected fractions were pooled, dialyzed, and lyophilized. The specific activity was 3,276.9 $\mathrm{AU} / \mathrm{mg}$ protein with a 4.07 -fold increase. Size exclusion chromatography using a Sephadex G-50 was done, and fraction numbers 30 to 33 showed
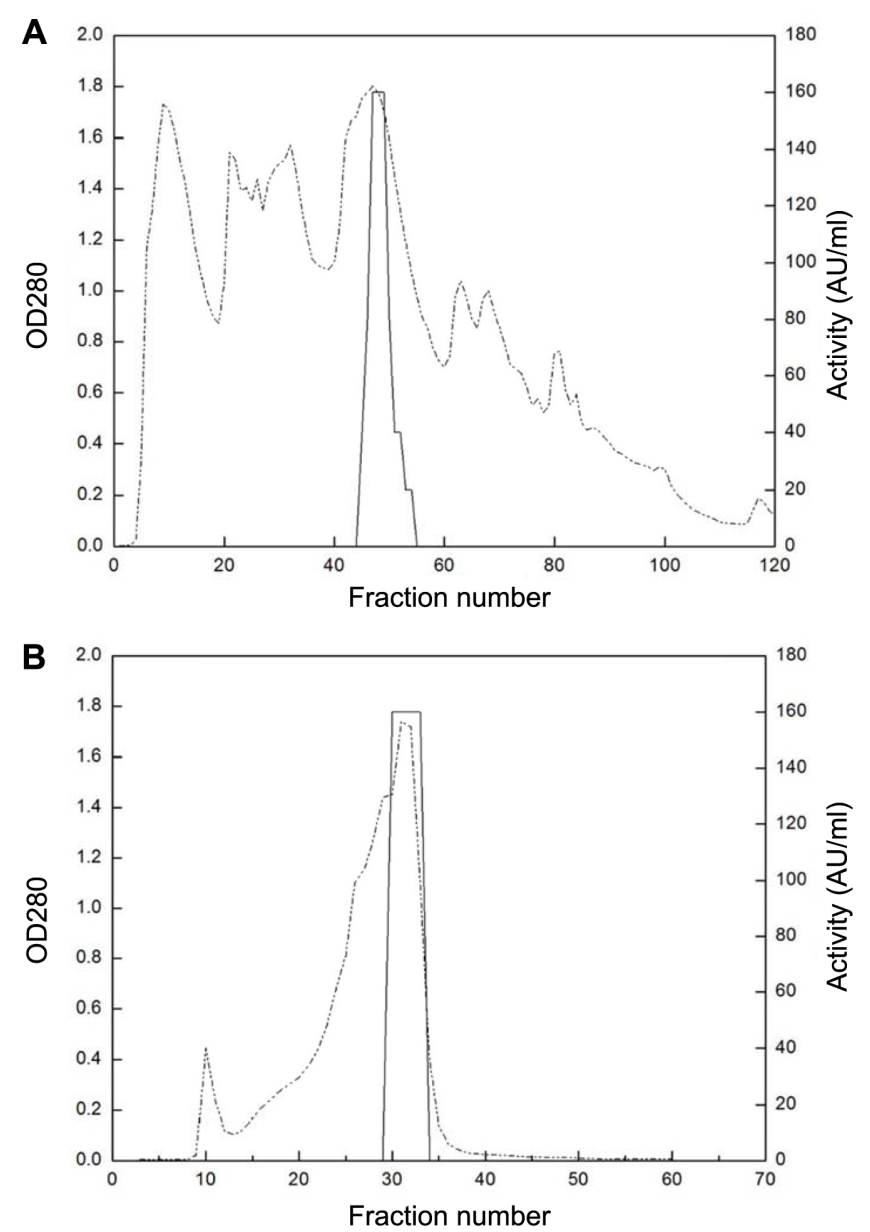

Fig. 2. Elution profiles of BacBS2 from Q-Sepharose column (A) and Sephadex G-50 column (B).

A dotted line indicates the absorbance values at $280 \mathrm{~nm}$ and a solid line denotes the bacteriocin activities $(\mathrm{AU} / \mathrm{ml})$.

antibacterial activity against $L$. monocytogenes ATCC19111 (Fig. 2B). After passage through a Sephadex G-50 column, the specific activity of BacBS2 was 7,069.8 AU/mg protein, which was an 8.8 -fold increase and an $8 \%$ yield from the initial purification step.

\section{Size of BacBS2 and FT-IR Analysis}

Partially purified BacBS2 (after Q-Sepharose fast flow column) was used as a sample for SDS-PAGE to determine the molecular size of BacBS2. After electrophoresis was done, half of the gel was washed, and overlaid with soft agar (0.7\% MHA) seeded with L. monocytogenes ATCC19111 culture grown until $\mathrm{OD}_{600}$ value of 0.4 . After incubation, a zone of inhibition was observed at $6.5 \mathrm{kDa}$ position (Fig. 3).

FT-IR spectroscopy is useful to categorize an unknown 


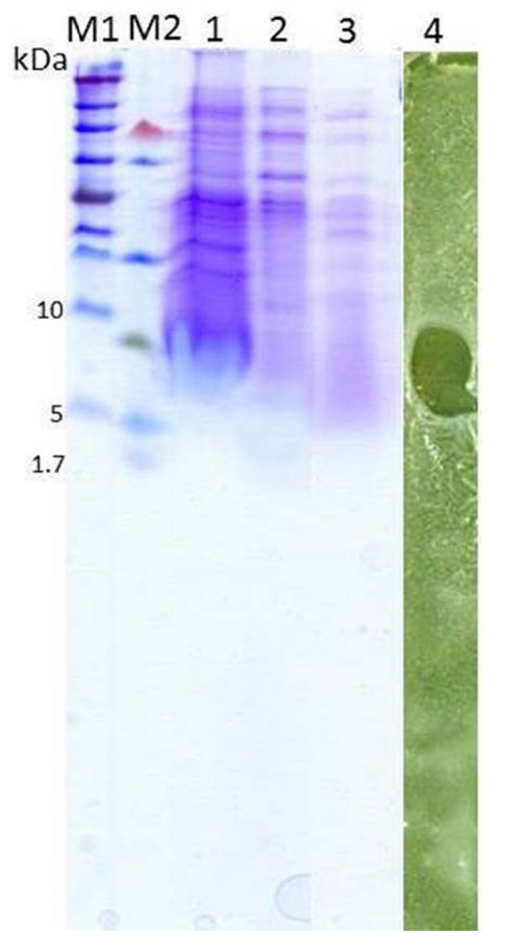

Fig. 3. Tricine SDS-PAGE and activity detection of BacBS2. M1, broad range protein markers (SMOBIO Technology, Inc., Hsinchu City, Taiwan); M2, low range protein markers (Cell Signaling Technology, Danvers, MA, USA); 1, dialyzed BacBS2 $(50 \mu \mathrm{g}) ; 2$, partially purified BacBS2 $(50 \mu \mathrm{g})$ after Q-Sepharose column; 3, partially purified sample $(50 \mu \mathrm{g})$ after Sephadex G-50 column; 4 , activity detection of BacBS2 by overlaying an acrylamide gel with soft agar containing $L$. monocytogenes cells.

compound by unraveling the presence of functional groups and chemical bonds. Intense broad peaks between 3,000 and $3,600 \mathrm{~cm}^{-1}$ indicate-OH and $\mathrm{NH}$ stretching in BacBS2 (Fig. 4). The observed peaks at 1,522, 1,630 $\mathrm{cm}^{-1}$ (Gauzian amide bond), correspond to peaks at 3,418 $\mathrm{cm}^{-1}$ (Hydrogen bond of $\mathrm{OH}$ group) designating the presence of peptide bonds. The peak at $1,630 \mathrm{~cm}^{-1}$ associated with spectrum between 3,500 and $3,183 \mathrm{~cm}^{-1}$ revealed the presence of amide group in BacBS2 [26]. The absorption peak at 2,986 results in C-H stretching and designates the existence of an aliphatic chain. The peak at 1,460 and 1,401 $\mathrm{cm}^{-1}$ arises from the amide II bond which results from the deformation of $\mathrm{N}-\mathrm{H}$ bond combined with $\mathrm{C}-\mathrm{N}$ stretching molecule [27]. The peaks at 1,630 and 1,552 $\mathrm{cm}^{-1}$ indicate the existence of amide I and amide II. Peaks of BacBS2 designated only the functional groups and bonds used to present in the protein and not for any lipid moiety, hence this result proved that BacBS2 has a proteinaceous nature.

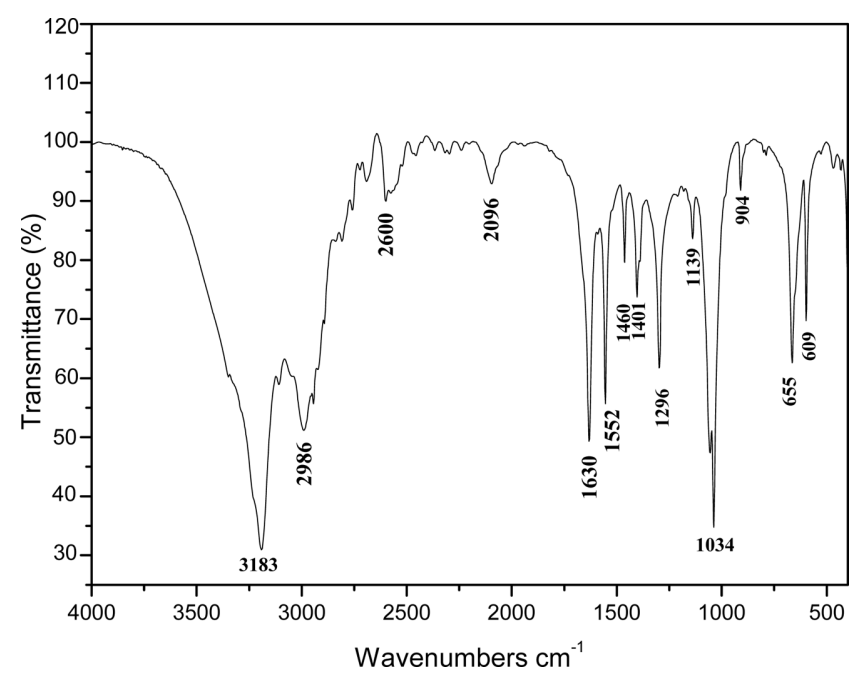

Fig. 4. FT-IR spectrum of partially purified BacBS2 $(50 \mu \mathrm{g} / \mathrm{ml})$.

\section{PCR Detection of Antimicrobial Genes from B. velezensis BS2}

PCR detection of genes of known bacteriocins and lipopeptides was tried using primers designed from commonly known genes (Table 3). The amplified PCR products were run using $1 \%$ agarose gels (Fig. 5). The results showed clear bands with expected sizes for the genes of lipopeptide surfactin (srfA, srf/lch), iturin (ituD) and iturin A (ituA). Bands were not found for the genes of surfactin ( $s f p$ ) and fengycin (fen). Though lipopeptide genes surfactin and iturin were present in B. velezensis BS2, the main antimicrobial compound was suspected to be a bacteriocin since CFS lost antibacterial activity upon proteinase-K treatment. Hence, commonly known genes of bacteriocins in Bacillus such as subtilin and subtilosin A were checked for the presence but their genes were not amplified.

A primer set for detection of $a c n A$ (encoding the precursor of amylocyclicin) was expected to produce a $702 \mathrm{bp}$ fragment. The size of amplified PCR product matched with the expected size. When the product was sequenced after extraction from the gel, the nucleotide sequence (Fig. 5B) showed $100 \%$ homology to acnA (amylocyclicin precursor gene) from $B$. velezensis FZB42, formly known as $B$. amyloliquefaciens FZB42 [28]. B. velezensis FZB42 is a model organism for plant-growth promoting rhizobacteria [28]. In addition to amylocyclicin, B. velezensis FZB42 produces non-ribosomally synthesized lipopeptides such as surfactin, fengycin, and bacillomycin $\mathrm{D}$, inhibiting plant pathogenic fungi [28]. 
A

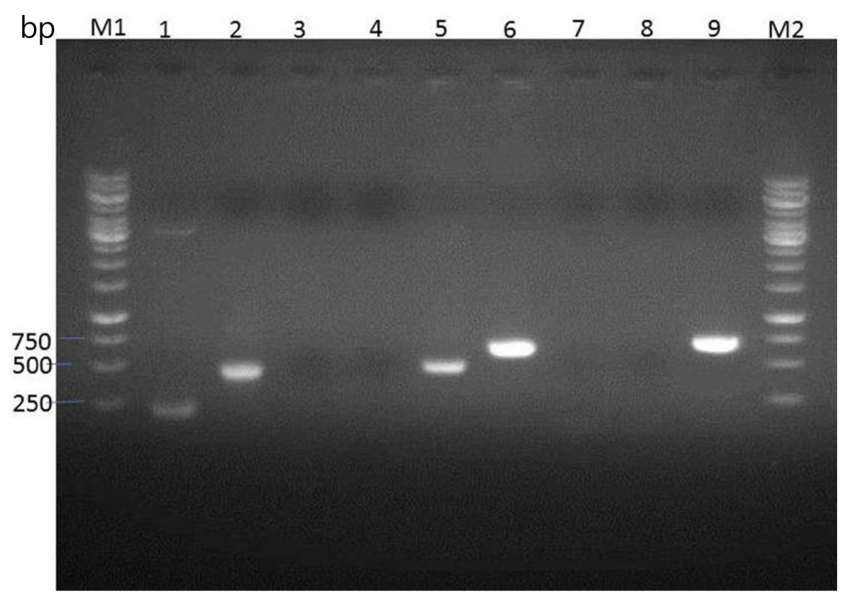

B

ATGAACTTAGTAAAATCTAATAAAAAGTCTTTCATTTTGTTTGGCGCGGCTCTTGCTGCA 60 $\begin{array}{lllllllllllllllllllllll}M & N & L & V & K & S & N & K & K & S & F & I & L & F & G & A & A & L & A & A\end{array}$ GCAACATTGGTTTATGCACTATTATTAACGGGAACTGAATTAAACGTGGCGGCGGCTCAT $\begin{array}{cccccccccccccccccccc}\text { A } & T & \text { L } & \text { V } & \text { Y } & \text { A } & \text { L } & \text { L } & \text { L } & \text { T } & \text { G } & \text { T } & \text { E } & \text { L } & \text { N } & \text { V } & \text { A } & \text { A } & \text { A } & \text { H } \\ \text { G }\end{array}$ $\begin{array}{lllllllllllllllllll}A & F & S & A & N & A & E & L & A & S & T & L & G & I & S & T & A & A & A\end{array}$ AAGCAATTGATATTATTGATGCGGCATCAACAATTGCTTCTATCATTTCTCTCATCGGT $\begin{array}{cccccccccccccccccccc}\text { K } & \text { A } & \text { I } & \text { D } & \text { I } & \text { I } & \text { D } & \text { A } & \text { A } & \text { S } & \text { T } & \text { I } & \text { A } & \text { S } & \text { I } & \text { I } & \text { S } & \text { L } & \text { I } & G \\ \text { ATCGGTACAGGCGCAGGCGCGATTTCTTATGCAATCGTTGCAACAGCAAAAACAATGATT } & \end{array}$ $\begin{array}{lllllllllllllllllllll}I & V & T & G & A & G & A & I & S & Y & A & I & V & A & T & A & K & T & M\end{array}$ AAGAAATACGGCAAAAAATACGCAGCTGCTTGGTAA

$\begin{array}{lllllllllllllll}K & K & Y & G & K & K & Y & A & A & A & W\end{array}$

Fig. 5. PCR detection of antimicrobial genes from B. velezensis BS2 genome.

A, M1 and M2, $1 \mathrm{~kb}$ DNA ladder (Thermo Scientific, Carlsbad, CA, USA); 1, srfA; 2, srf/lch; 3, sfP; 4, fen; 5, ituA; 6, ituD; 7, spaS; 8, sboA; 9, acn $A$. B, partial nucleotide sequence of the PCR product (A, lane 9) and the translated amino acids.

Two bacteriocin genes encoding amylolysin and amylocyclicin were located after the examination of whole genome sequences of B. velezensis LS69 [29]. Amylocyclicin is a ribosomally synthesized circular bacteriocin with growth inhibition specificity against Gram-positive bacteria and its molecular weight was calculated to be 6.38-6.40 kD [30]. Moreover, B. velezensis strains are known to produce antimicrobial lipopeptides such as surfactin, iturin and fengycin with a molecular weight ranging from 1 to $2 \mathrm{kDa}$ $[31,32]$. Lipopeptides of $B$. velezensis BS2 were precipitated by acid precipitation using $6 \mathrm{~N} \mathrm{HCl}$ and the antibacterial activity was checked by agar well diffusion method. But a negligible or small zone of inhibition was observed by lipopeptide precipitate (data not shown). By considering the inhibition specificity for Gram-positive bacterial strains and molecular weight of active peptide (around $6.5 \mathrm{kDa}$ ), and loss of activity upon proteinase-K treatment, bacteriocin BS2 may possibly be amylocyclicin. Successful detection of the amylocyclicin gene from the BS2 genome could be supporting evidence. BLAST analysis of the translated amino acids (Fig. 5B) showed that amylocyclicin is a member of circular bacteriocins (circularin A/uberolysin family), which are widely present among Gram-positive bacteria such as Bacillus, Paenibacillus, Gracilibacillus, and Staphylococcus. Putative amylocyclicins translated from genes are highly conservative among B. amyloliquefaciens (99\%) and B. subtilis groups (97\%).

However, the possibility can't be ruled out that BacBS2 is a different bacteriocin. Inhibition spectrum of BacBS2 is different from that of amylocyclicin. BacBS2 does not inhibit B. licheniformis and B. subtilis but amylocyclicin does. BacBS2 inhibits B. cereus strongly but amylocyclicin inhibits weakly [26]. As a member of circular bacteriocins, amylocyclicin possesses high thermostability but the thermostability of BacBS2 is not that high. B. velezensis FZB42 is an organism originated from soil and plants but $B$. velezensis BS2 was isolated from meongge (common sea squirt) jeotgal, originated from marine environments. Considering these facts, BacBS2 might be a novel bacteriocin not reported yet, but further studies such as Nterminal amino acid sequencing of BacBS2 are necessary before a definite conclusion can be reached. As far as we know, this is the first report on a bacteriocin produced by a $B$. velezensis strain originated from marine environments.

\section{Mode of Action of BacBS2}

The viable count of L. monocytogenes ATCC19111 was reduced from $7.25 \log \mathrm{CFU} / \mathrm{ml}$ to $6.27 \log \mathrm{CFU} / \mathrm{ml}$ at $3 \mathrm{~h}$ after addition of BacBS2 $(100 \mu \mathrm{g})$, and decreased continuously (Fig. 6). The viable count was further decreased to $3.8 \mathrm{log}$ $\mathrm{CFU} / \mathrm{ml}$ at $12 \mathrm{~h}$ after addition. On the contrary, the viable count of control increased continuously (Fig. 6). The results suggested that BacBS2 killed sensitive L. monocytogenes ATCC19111 cells. The bacteriocidal mode of inhibition is often reported for bacteriocins synthesised by Grampositive bacteria including Bacillus species [33].

$B$. velezensis BS2 was originated from marine environments. It was isolated from meongge (common sea squirt) jeotgal, a Korean fermented seafood prepared from just salt and meongge. B. velezensis BS2 grows well at $15 \% \mathrm{NaCl}(\mathrm{w} / \mathrm{v})$ and at $10^{\circ} \mathrm{C}$. Thus $B$. velezensis BS2 seems promising as a starter for salted and fermented foods such as fish sauce and jeotgal. B. velezensis BS2 produces a bacteriocin, BacBS2, which strongly inhibits important food pathogens such as L. monocytogenes and B. cereus. This property is a big advantage for $B$. velezensis BS2 as a starter. In addition to bacteriocin production, the strain secretes a protease with strong fibrinolytic activity [7]. Finally, B. velezensis 


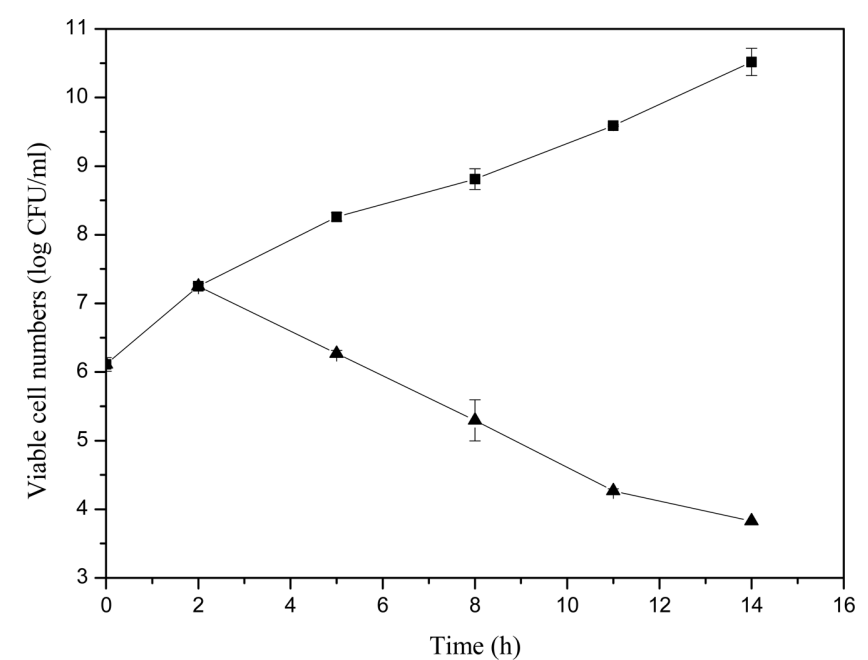

Fig. 6. Mode of inhibition of L. monocytogenes ATCC19111 by BacBS2.

- viable counts of L. monocytogenes (log CFU/ml) culture without BacBS2 addition; $\longrightarrow$, viable counts of L. monocytogenes $(\log \mathrm{CFU} / \mathrm{ml})$ culture treated with BacBS2.

strains can be considered GRAS organisms considering their close relationship with B. amyloliquefaciens [34]. Considering all these, $B$. velezensis BS2 and BacBS2 may be used as a natural food preservative for fermented foods replacing chemical preservatives.

\section{Acknowledgments}

This work was supported by the Basic Science Research Program through the National Research Foundation of Korea (NRF) funded by the Ministry of Education (2017R1D1A1B03030037), and also supported by grant 20130290 to the Solar Salt Research Center of Mokpo National University from the Ministry of Oceans and Fisheries of Korea. Zhuang Yao and Jeong A Kim were supported by the BK21 Plus Program, MOE, Republic of Korea.

\section{Conflict of Interest}

The authors have no financial conflicts of interest to declare.

\section{References}

1. Sumi CD, Yang BW, Yeo IC, Hahm YT. 2015. Antimicrobial peptides of the genus Bacillus: a new era for antibiotics. Can. J. Microbiol. 61: 93-103.
2. Stein T. 2005. Bacillus subtilis antibiotics: structures, syntheses and specific functions. Mol. Microbiol. 56: 845-857.

3. Leite JA, Tulini FL, dos Reis-Teixeira FB, Rabinovitch L, Chaves JQ, Rosa NG, et al. 2016. Bacteriocin-like inhibitory substances (BLIS) produced by Bacillus cereus: preliminary characterization and application of partially purified extract containing BLIS for inhibiting Listeria monocytogenes in pineapple pulp. LWT-Food Sci. Technol. 72: 261-266.

4. Abdel-Mohsein H, Yamamoto N, Otawa K, Tada C, Nakai Y. 2010. Isolation of bacteriocin-like substances producing bacteria from finished cattle-manure compost and activity evaluation against some food-borne pathogenic and spoilage bacteria. J. Gen. Appl. Microbiol. 56: 151-161.

5. Chehimi S, Delalande F, Sablé S, Hajlaoui MR, Van Dorsselaer A, Limam F, et al. 2007. Purification and partial amino acid sequence of thuricin $S$, a new anti-Listeria bacteriocin from Bacillus thuringiensis. Can. J. Microbiol. 53: 284-290.

6. Martirani L, Varcamonti M, Naclerio G, De Felice M. 2002. Purification and partial characterization of bacillocin 490, a novel bacteriocin produced by a thermophilic strain of Bacillus licheniformis. Microb. Cell Fact. 1: 1-5.

7. Yao Z, Kim JA, Kim JH. 2019. Characterization of a fibrinolytic enzyme secreted by Bacillus velezensis BS2 isolated from sea squirt jeotgal. J. Microbiol. Biotechnol. 29: 347-356.

8. Ye M, Tang X, Yang R, Zhang H, Li F, Tao F, et al. 2018. Characteristics and application of a novel species of Bacillus: Bacillus velezensis. ACS Chem. Biol. 13: 500-505.

9. Cho MS, Jin YJ, Kang BK, Park YK, Kim C, Park DS. 2018. Understanding the ontogeny and succession of Bacillus velezensis and B. subtilis subsp. subtilis by focusing on kimchi fermentation. Sci. Rep. 8: 7045.

10. Yi Y, Zhang Z, Zhao F, Liu H, Yu L, Zha J, Wang G, 2018. Probiotic potential of Bacillus velezensis JW: antimicrobial activity against fish pathogenic bacteria and immune enhancement effects on Carassius auratus. Fish Shellfish Immunol. 78: 322-330.

11. Nam MH, Park MS, Kim HG, Yoo SJ. 2009. Biological control of strawberry Fusarium wilt caused by Fusarium oxysporum f. sp. fragariae using Bacillus velezensis BS87 and RK1 formulation. J. Microbiol. Biotechnol. 19: 520-524.

12. Giongo JL, Lucas FS, Casarin F, Heeb P, Brandelli A. 2007. Keratinolytic proteases of Bacillus species isolated from the Amazon basin showing remarkable de-hairing activity. World J. Microbiol. Biotechnol. 23: 375-382.

13. Ruiz-Garcia C, Bejar V, Martinez-Checa F, Llamas I, Quesada E. 2005. Bacillus velezensis sp. nov., a surfactantproducing bacterium isolated from the river Vélez in Málaga, southern Spain. Int. J. Syst. Evol. Microbiol. 55: 191-195.

14. Gao YH, Guo RJ, Li SD. 2018. Draft genome sequence of Bacillus velezensis $\mathrm{B} 6$, a rhizobacterium that can control plant diseases. Genome Announc. 6(12): e00182-18. 
15. Baptista JP, Sanches PP, Teixeira GM, Morey AT, Tavares ER, Yamada-Oqatta SF, et al. 2018. Complete genome sequence of Bacillus velezensis LABIM40, an effective antagonist of fungal plant pathogens. Genome Announc. 6: e00595-18.

16. Kamoun F, Mejdoub H, Aouissaoui H, Reinbolt J, Hammami A, Jaoua S. 2005. Purification, amino acid sequence and characterization of Bacthuricin F4, a new bacteriocin produced by Bacillus thuringiensis. J. Appl. Microbiol. 98: 881-888.

17. Bradford MM. 1976. Rapid and sensitive methods for the quantification of microgram quantities of protein utilizing the principle of protein-dye binding. Anal. Biochem. 72: 248254.

18. Schägger H, von Jagow G. 1987. Tricine-sodium dodecyl sulphate polyacrylamide gel electrophoresis for the separation of protein in the range from 1 to $100 \mathrm{kDa}$. Anal. Biochem. 166: 368-379.

19. Liu X, Lee JY, Jeong SJ, Cho KM, Kim GM, Shin JH, et al. 2015. Properties of a bacteriocin produced by Bacillus subtilis EMD4 isolated from ganjang (soy sauce). J. Microbiol. Biotechnol. 25: 1493-1501.

20. Liu X, Shim JM, Yao Z, Lee JY, Lee KW, Kim HJ, et al. 2016. Properties of antimicrobial substances produced by Bacillus amyloliquefaciens CJW15 and Bacillus amyloliquefaciens SSD8. Microbiol. Biotechnol. Lett. 44: 9-18.

21. Chung S, Kong H, Buyer JS, Lakshman DK, Lydon J, Kim SD, et al. 2008. Isolation and partial characterization of Bacillus subtilis ME488 for suppression of soilborne pathogens of cucumber and pepper. Appl. Microbiol. Biotechnol. 80: 115-123.

22. Tapi A, Chollet-Imbert M, Scherens B, Jacques P. 2010. New approach for the detection of non-ribosomal peptide synthetase genes in Bacillus strains by polymerase chain reaction. Appl. Microbiol. Biotechnol. 85: 1521-1531.

23. Athukorala SN, Fernando WG, Rashid KY. 2009. Identification of antifungal antibiotics of Bacillus species isolated from different microhabitats using polymerase chain reaction and MALDI-TOF mass spectrometry. Can. J. Microbiol. 55: 10211032.

24. Sutyak KE, Wirawan RE, Aroutcheva AA, Chikindas ML. 2008. Isolation of the Bacillus subtilis antimicrobial peptide subtilosin from the dairy product-derived Bacillus amyloliquefaciens. J. Appl. Microbiol. 104: 1067-1074.
25. Cintas LM, Casaus P, Fernández MF, Hernández PE. 1998. Comparative antimicrobial activity of enterocin L50, pediocin PA-1, nisin A and lactocin S against spoilage and foodborne pathogenic bacteria. Food Microbiol. 15: 289-298.

26. Benitez LB, Velho RV, Lisboa MP, da Costa Medina LF, Brandelli A. 2010. Isolation and characterization of antifungal peptides produced by Bacillus amyloliquefaciens LBM5006. J. Microbiol. 48: 791-797.

27. Perumal V, Repally A, Dasari A, Venkatesan A. 2016. Partial purification and characterization of bacteriocin produced by Enterococcus faecalis DU10 and its probiotic attributes. Prep. Biochem. Biotechnol. 46: 686-694.

28. Fan B, Wang C, Song X, Ding X, Wu L, Wu H, Gao X, Borriss R. 2018. Bacillus velezensis FZB42 in 2018: the grampositive model strain for plant growth promotion and biocontrol. Front. Microbiol. 9: 2491.

29. Liu G, Kong Y, Fan Y, Geng C, Peng D, Sun M. 2017. Whole-genome sequencing of Bacillus velezensis LS69, a strain with a broad inhibitory spectrum against pathogenic bacteria. J. Biotechnol. 249: 20-24.

30. Scholz R, Vater J, Budiharjo A, Wang Z, He Y, Dietel K, et al. 2014. Amylocyclicin, a novel circular bacteriocin produced by Bacillus amyloliquefaciens FZB42. J. Bacteriol. 196: 18421852.

31. Cao Y, Pi H, Chandrangsu P, Li Y, Wang Y, Zhou H, et al. 2018. Antagonism of two plant-growth promoting Bacillus velezensis isolates against Ralstonia solanacearum and Fusarium oxysporum. Sci. Rep. 8: 4360.

32. Adeniji AA, Aremu OS, Babalola OO. 2018. Selecting lipopeptide-producing, Fusarium-suppressing Bacillus spp.: metabolomic and genomic probing of Bacillus velezensis NWUMFkBS10. 5. MicrobiologyOpen 8(6): e00742.

33. Uqras S, Sezen K, Kati H, Demirbaq Z. 2013. Purification and characterization of the bacteriocin Thuricin Bn1 produced by Bacillus thuringiensis subsp. kurstaki Bn1 from a hazelnut pest. J. Microbiol. Biotechnol. 23: 167-176.

34. Fan B, Blom J, Klenk HP, Borriss R. 2017. Bacillus amyloliquefaciens, Bacillus velezensis, and Bacillus siamensis form an "operational group B. amyloliquefaciens" within the B. subtilis species complex. Front. Microbiol. 8: 22. 